\title{
Railroad Vine (Ipomoea pes-caprae): Identification and
} Uses $^{1}$

\author{
Stephen H. Brown and Marc S. Frank ${ }^{2}$
}

Family: Convolvulaceae (morning-glory and sweet potato family)

Common Names: railroad vine, bayhops, beach morningglory, seaside yam, goat's foot, goat's foot morning-glory, goat's foot creeper

Origin: pantropical, including Florida and tropical and subtropical Americas, Africa, Asia, Australia and the Pacific Islands

USDA Zone: $9 \mathrm{~A}-12\left(20^{\circ} \mathrm{F}\right.$ minimum $)$

Plant Type: creeping perennial vine (rarely climbing)

Growth Rate: fast

Typical Length: may extend to over 100 feet

Leaf Type: alternate, simple, entire, often with a notched apex

Leaf Persistence: evergreen

Flower Type: axillary, funnelform

Flower Color: pink to lavender, reddish-purple, or violet (rarely white)

Flowering months: all year, peaking in May through November
Fruit Type: 4-chambered, dehiscent capsule

Fruit Color: brown and smooth becoming gray

Light Requirements: full sun

Soil Requirements: sandy, free draining, alkaline to slightly acidic

Drought Tolerance: high

Salt Tolerance: high

Wind Tolerance: high

Nutritional Requirements: low

Propagation: tissue culture, cuttings, division, seed

IFAS Assessment: not assessed (native)

Regulatory Status: not listed

Human Hazards: all parts are potentially poisonous if consumed

Occasional Problems: beetles, scales, slugs, leaf spots, rust Uses: beach stabilizer, flowering groundcover, coastal and inland plantings

1. This document is ENH1323, one of a series of the Environmental Horticulture Department, UF/IFAS Extension. Original publication October 2020. Visit the EDIS website at https://edis.ifas.ufl.edu for the currently supported version of this publication.

2. Stephen H. Brown, horticulture agent, UF/IFAS Extension Lee County; and Marc S. Frank, Extension botanist, UF/IFAS Plant Identification and Information Service, University of Florida Herbarium; UF/IFAS Extension, Gainesville, FL 32611.

The Institute of Food and Agricultural Sciences (IFAS) is an Equal Opportunity Institution authorized to provide research, educational information and other services

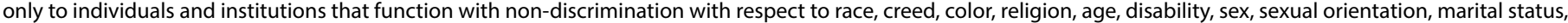

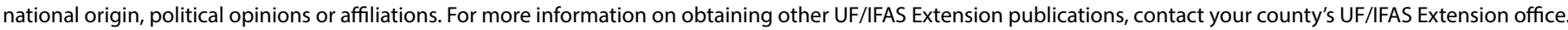
U.S. Department of Agriculture, UF/IFAS Extension Service, University of Florida, IFAS, Florida A \& M University Cooperative Extension Program, and Boards of County Commissioners Cooperating. Nick T. Place, dean for UF/IFAS Extension. 


\section{Nomenclature}

\begin{tabular}{|l|l|}
\hline Kingdom & Plantae \\
\hline Phylum & Magnoliophyta \\
\hline Class & Eudicotyledones \\
\hline Order & Solanales \\
\hline Genus & Convolvulaceae \\
\hline Species & \begin{tabular}{l} 
Ipomoea \\
\hline Ipomoea pes-caprae (L.) R. Br.
\end{tabular} \\
$\begin{array}{l}\text { Convolvulus bilobatus Roxb., C. brasiliensis L., C. } \\
\text { maritimus Lam., C. pes-caprae L., Ipomoea biloba Forssk., } \\
\text { I. bilobata var. emarginata (Hallier f.) R. O. Williams, } \\
\text { Ibrasiliensis (L.) G. Mey., I. brasiliensis (L.) Sweet, I. } \\
\text { maritima (Desr.) R. Br., I. pes-caprae subsp. brasiliensis } \\
\text { (L.) Ooststr., I. pes-caprae var. emarginata Hallier f. } \\
\text { Latrienda brasiliensis (L.) Raf. }\end{array}$ \\
\hline
\end{tabular}

\section{Geographic Distribution and Habit}

Railroad vine is one of the most widely distributed beach plants in the world. Its exact native range is obscure, but railroad vine is now found in subtropical and tropical zones worldwide, including the West Indies, the Americas, Africa, Asia, Australia, and the Pacific Islands. In the United States, it occurs along the Atlantic coast of Georgia and Florida, and along the Gulf coast from Florida to Texas. It is primarily found in coastal habitats, especially dunes and beaches, and is rarely found inland. The moving sand and salt spray make the beach environment a harsh one, and the plants that live there are specialized to colonize that environment.

This is a tap-rooted, herbaceous, creeping (rarely twining), perennial vine that produces a milky latex when broken. It grows rapidly and usually does not form a dense cover on Florida's beaches. The common name "railroad vine" refers to its tendency to form "tracks" of horizontal stems more than 100 feet long.

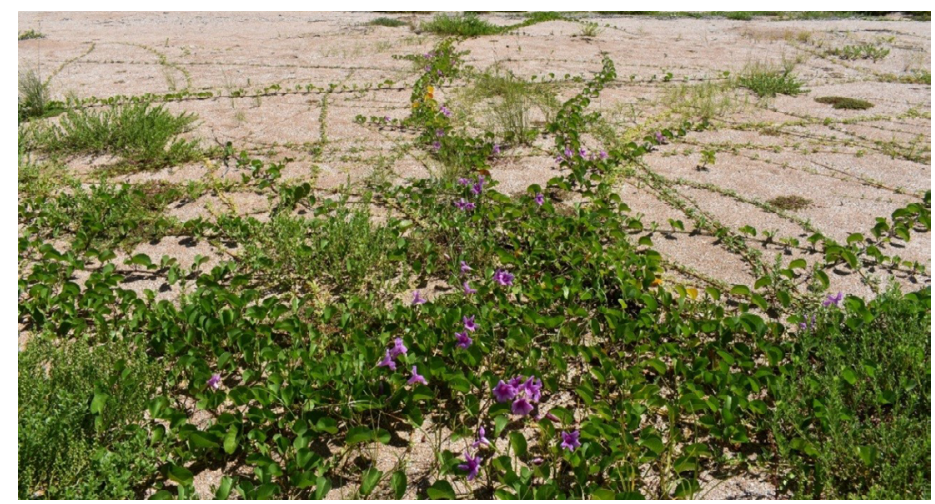

Figure 1. Creeping habit of railroad vine.

Credits: Stephen H. Brown, UF/IFAS

The stems are succulent, becoming tough and fibrous with age. Nodes are mostly 3 to 7 inches apart. Adventitious roots often form at the nodes, helping to anchor the vine. Stems are typically horizontal, but when the plant encounters something to climb upon, they may occasionally twine upward. Plants usually are between 6 to 16 inches in height.

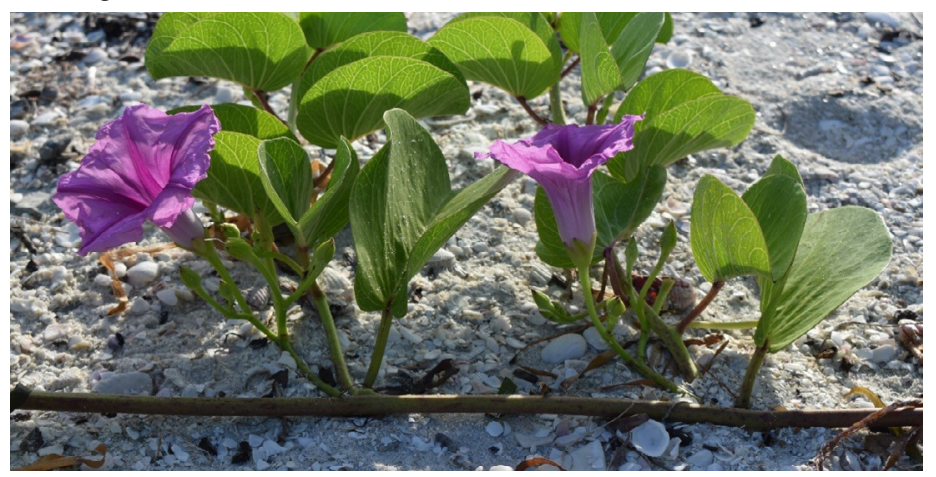

Figure 2. Plants often form adventitious roots at the nodes. Flowers are axillary.

Credits: Stephen H. Brown, UF/IFAS

\section{Leaves}

The leaves are simple, alternately arranged, dark green, rather leathery, and glabrous (hairless). Leaf shape is quite variable in this species but is typically ovate (egg-shaped), orbicular (circular), or oblong (parallel-sided). The leaf base is truncate to shallowly cordate (heart-shaped), and the apex is usually notched to deeply cleft, but sometimes rounded or truncate. The epithet pes-caprae is Latin for "goat's foot," referring to the notched leaf apex (resembling the cloven hoof of a goat). The leaf blades are usually 3.0 to 4.75 inches long and 3.5 to 6.0 inches wide, and they are often folded upward from the midrib. The veins on the leaf blades are pinnate and finely reticulate (net-like), typically more visible on the leaf undersides than on the upper surface. The petioles (leaf stalks) vary in length ranging from 1 to 6 inches. On young leaves, the petioles are commonly reddish in color, becoming yellowish-green as they age. There is a pair of nectar-producing glands on the underside of each leaf blade at its juncture with the petiole. These nectaries are red on new leaves, turning black with age, and attract ants, which defend the plant against herbivorous insects.

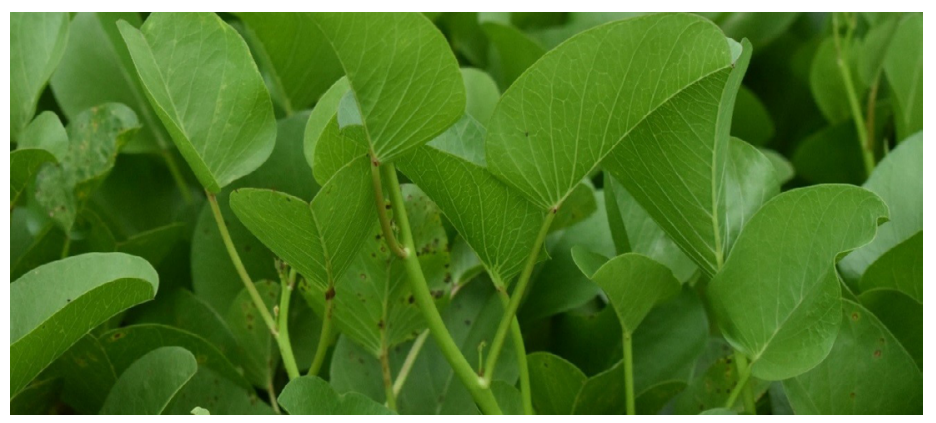

Figure 3. Leaves are alternate, glabrous, often notched at the tips, and folded upwards. Note the paired red nectaries at the juncture of the petiole and the leaf base on the three leaves in the center of the photo.

Credits: Stephen H. Brown, UF/IFAS 


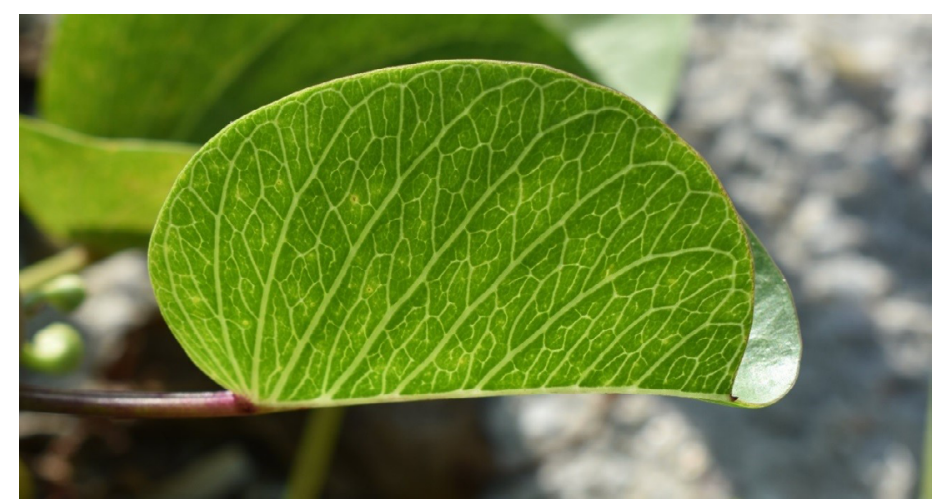

Figure 4. The veins are pinnate and reticulate (net-like), often more noticeable on the leaf undersides.

Credits: Stephen H. Brown, UF/IFAS

\section{Flowers}

Flowers may be produced year-round but are most abundant during the warmer months (from spring to fall), and less common in winter. Each flower lasts only one day, opening at sunrise and closing by early afternoon on sunny days. On cloudy days, flowers often open and close later. Railroad vine is an obligate out-crosser, meaning the flowers are self-incompatible (self-pollinated flowers result in very few or no fruit). Insects attracted to the large nectaries of the showy flowers assist in cross-pollination. The primary pollinators are bees, but butterflies, moths, flies, beetles, wasps, and ants may also visit the flowers.

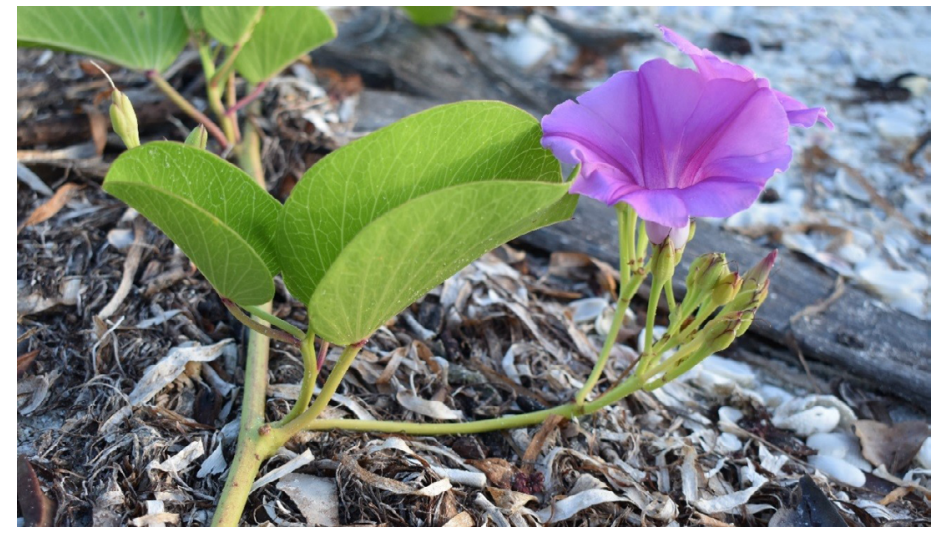

Figure 5. Flowers are borne in single- to few-flowered cymes at the leaf axils.

Credits: Stephen H. Brown, UF/IFAS

Flowers are borne in one-to-several-flowered cymes in the leaf axils. They are upright and funnel-shaped, consisting of five fused petals, often with notches along the edges at the juncture between adjacent petals. Flower color varies from pale pink to lavender to reddish purple (very rarely white), typically with a darker rose-purple throat radiating as bands up the midline of each petal, which serves as a nectar guide for pollinating insects. Corollas usually measure about 1.5 to 2.5 inches long and wide, and are borne on pedicels 1 to 2 inches long. The sepals are leathery, hairless, and unequal-the outer two shorter and ovate to elliptic and the inner three longer, almost circular in shape, with a rounded apex ended in a very small abrupt point (mucro).

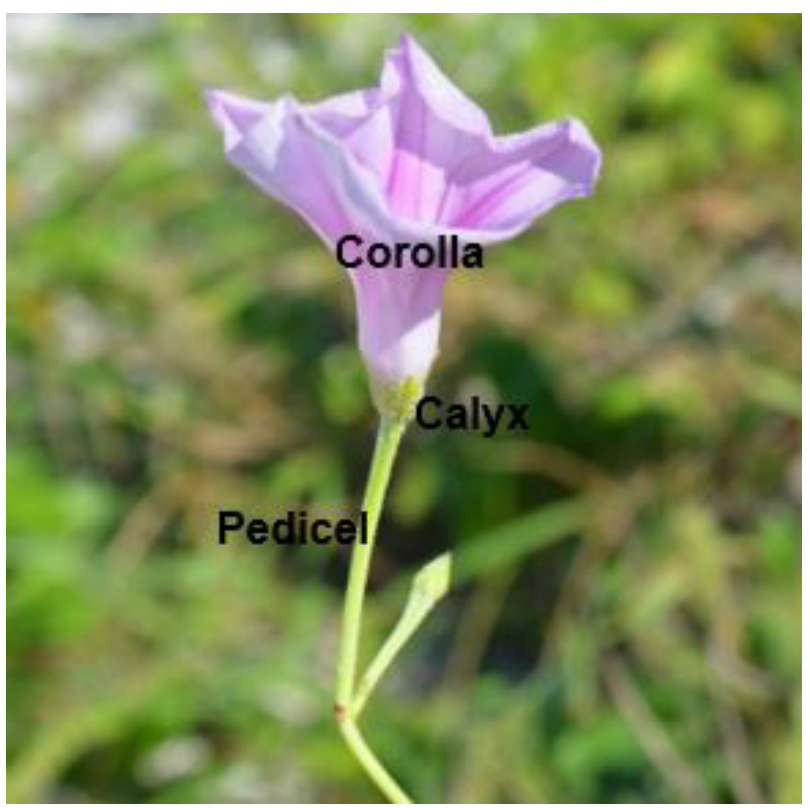

Figure 6. Flowers are upright, funnel-shaped, pink to lavender to reddish purple.

Credits: Stephen H. Brown, UF/IFAS

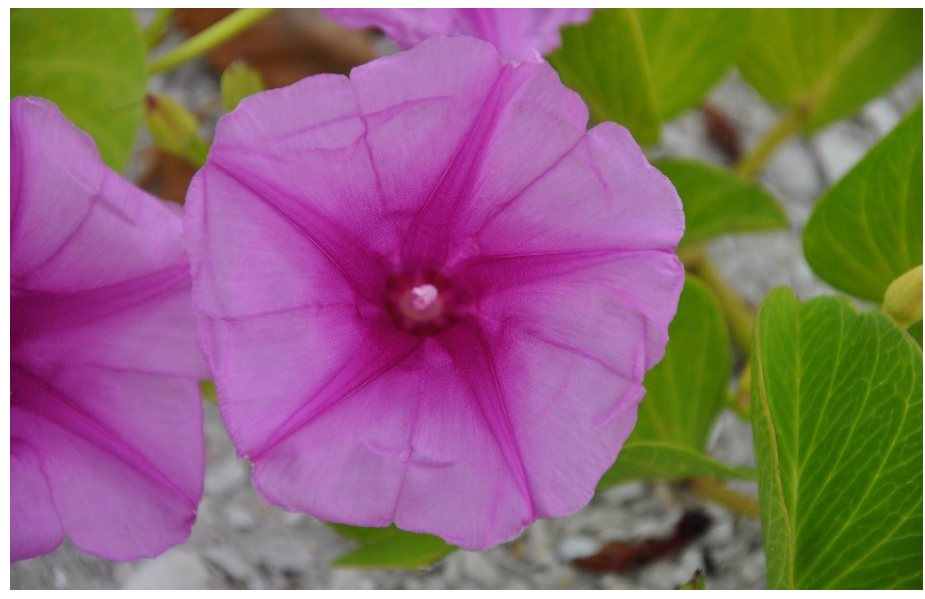

Figure 7. Five rose-purple markings radiate from the throats up the center of each of the fused petals.

Credits: Stephen H. Brown, UF/IFAS

\section{Fruit}

The fruit are ovoid to flattened-globose, dehiscent capsules, usually measuring 0.5 to 0.75 inches long and wide.

Capsules are borne on elongated pedicels with a persistent calyx. They are green and smooth when immature splitting into four valves at maturity. Opened capsules are leathery, brown on the exterior, and beige on the inside, becoming more brittle and gray with age. Each valve holds a single seed, which is rounded to trigonous (three-sided), covered with dense, velvety hairs, and 0.25 to 0.35 inches long. The seeds, sometimes referred to as seabeans or drift seeds, are adapted for dispersal on ocean currents and are sometimes collected after washing up on beaches. 


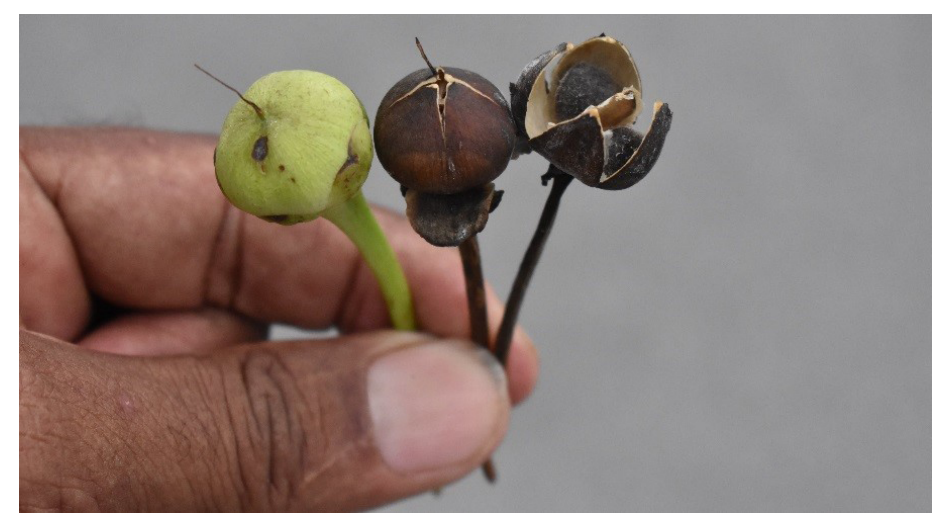

Figure 8. Immature fruit are green, turning brown and splitting into four valves at maturity.

Credits: Stephen H. Brown, UF/IFAS

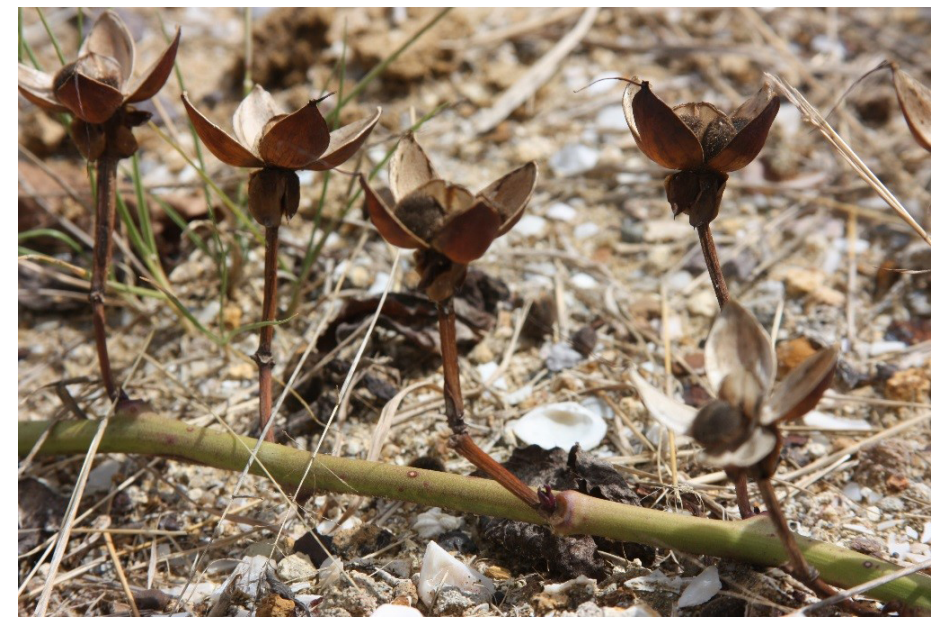

Figure 9. Capsules borne on elongated pedicels with persistent sepals. A close look shows seeds in the capsules.

Credits: Stephen H. Brown, UF/IFAS

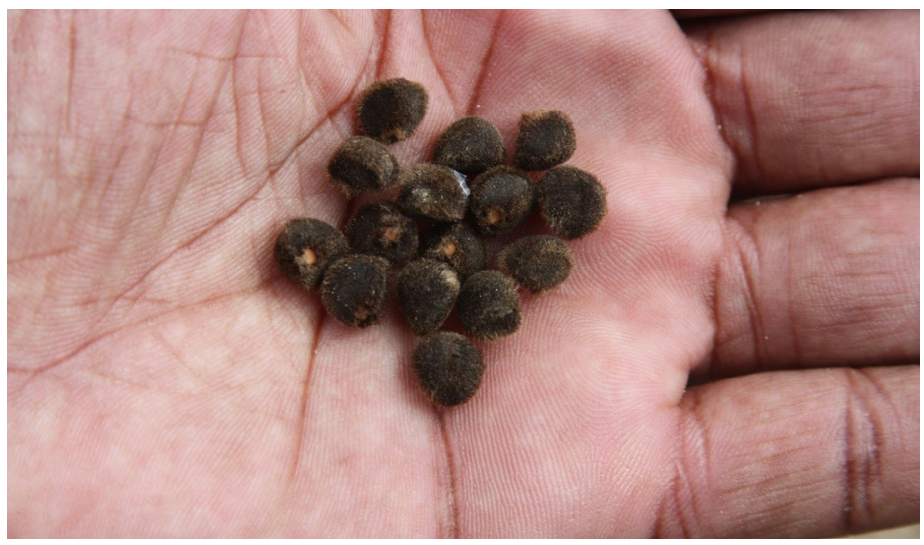

Figure 10. The seeds are small, rounded to three-angled, and covered with fine, brown hairs.

Credits: Stephen H. Brown, UF/IFAS

\section{Propagation}

Railroad vine is propagated by stem cuttings, seed, and tissue culture. Cuttings are generally faster and easier, and they have a higher transplant survival rate than plants produced from seed. Cuttings should be planted directly into a well-drained substrate with at least one node buried. Cuttings usually root within 7 to 10 days when grown under mist. To avoid rotting, cuttings should be removed from the mist to harden off as soon as they are rooted and may be transplanted to individual pots when roots are sufficiently developed. Gardeners can place cuttings to root in pots or directly into the ground and hand-water them until roots are well-developed. Seeds must be abraded or scarified before they will germinate. In the wild in Florida, seeds germinate much of the year except in winter.

\section{Uses, Planting, and Maintenance Guidelines}

Being native to dunes and beaches, railroad vine can tolerate intense heat, full sun, and poor soils, but it requires excellent drainage. It is used to stabilize beaches and dunes but may also be cultivated as an inland groundcover.

In south Florida, plant cuttings from March through October to form a groundcover on beaches, dunes, and landscapes. Railroad vine may be used on slopes up to $20^{\circ}$, and on steeper slopes if stable. Space small plants 2 to 3 feet apart, and 3 to 5 feet apart for larger plants. Plant with the top of the root ball slightly below the soil's surface. Irrigate at the time of planting and for several weeks thereafter unless there is regular rainfall. Providing regular water and controlling weeds will speed establishment of new plantings. For faster and denser coverage, redirect errant stems back into the growing area. Dense coverage is possible in two to three years on moist well-drained soil.

If inundated with salt water even for a short time, the aboveground portion will die back but typically regrow from the roots. However, long periods of saltwater inundation may kill the entire plant. Strong offshore wind may temporarily damage plants on beaches and dunes, causing scorched leaves and stems.

Ornamental groundcover plantings of railroad vine generally do not last for more than eight years. Insects, diseases, and improper management may hasten their decline. In the worst of landscape conditions, railroad vine longevity may not exceed a year. For best growth as a groundcover, the soil must be free-draining and irrigation kept to a minimum once the plants are established. Provide plenty of space and avoid interplanting with other small, low-growing species. Otherwise, fast-growing railroad vine is likely to overgrow smaller plants and require frequent pruning to keep it in bounds. In the landscape, railroad vine can tolerate occasional pruning, which encourages more branching. It does not tolerate shade and is easily out-competed by large plants that exclude light. In the drier winter and spring 
months, the plants may appear scraggly, but they will quickly recover at the start of the rainy season.

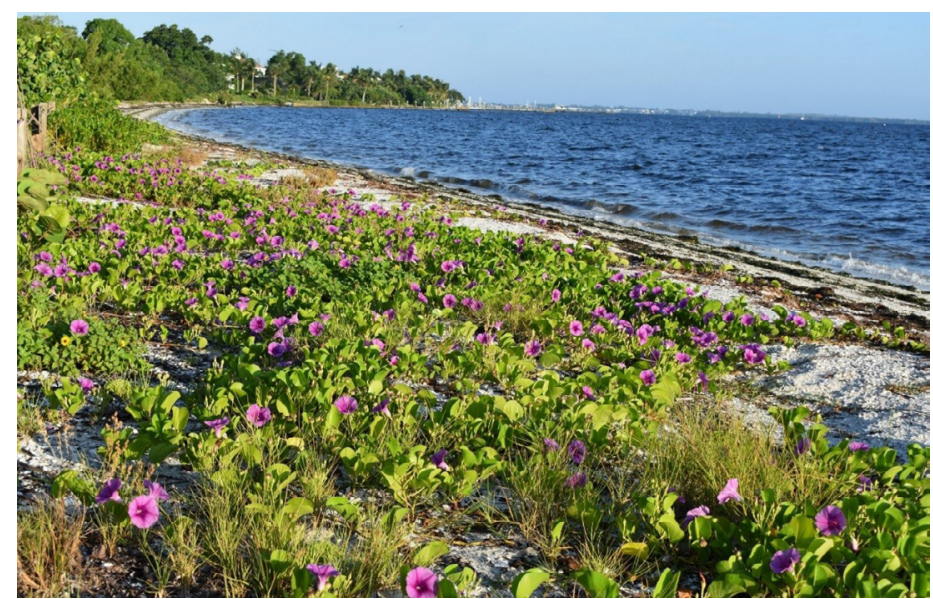

Figure 11. Railroad vine used as a beach stabilizer.

Credits: Stephen H. Brown, UF/IFAS

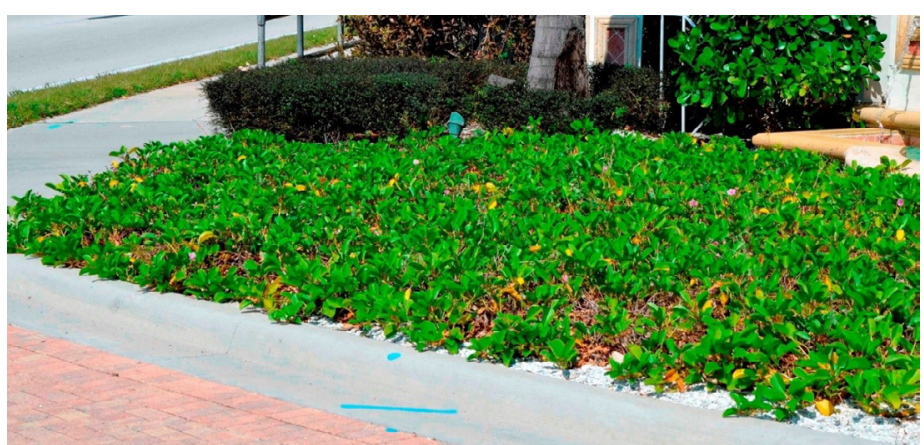

Figure 12. Railroad vine as a landscape groundcover.

Credits: Stephen H. Brown, UF/IFAS

\section{Insect, Slug, and Disease Problems}

\section{Sweet Potato Beetle}

The sweet potato beetle (Typophorus nigritus) occurs in most of the southeastern United States. Adults, which are black and shiny, feed in groups on the foliage of sweetpotato and morning glories (including railroad vine), causing defoliation. Eggs are laid in or near the soil surface at the base of a plant. Larvae are pale yellow with six small legs, are nearly $1 / 2$ inch long, and develop on the roots and stems. They first burrow through the stems and later tunnel through the roots, causing major damage to both tissues.

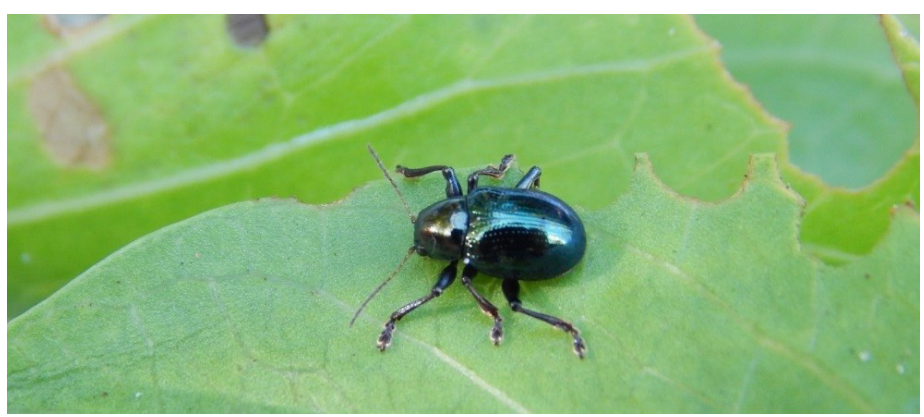

Figure 13. Adult sweet potato beetle on railroad vine leaf. Credits: Douglas Caldwell, UF/IFAS

\section{Scales and Mealybugs}

Scales and mealybugs are sometimes found on railroad vines but apparently are not debilitating to the plants.

The white peach scale (Pseudaulacaspis pentagona) is an armored scale that does not produce honeydew and consequently is not associated with sooty mold. It is believed to originate in Japan or China, but it is now found around the world. It most likely to be found on the stems of railroad vines. In Florida, there are as many as four generations per year. Several predators feed on white peach scale.

Philephedra tuberculosa, sometimes called the Philephedra scale, is a type of soft scale. Live females are oval or elongate oval in shape and yellow or green in color. They occur on leaves, stems, or fruit of the host plant.

The Madeira mealybug (Phenacoccus madeirensis) is a subtropical species of mealybug. It is found on a wide variety of plants and can cause serious damage.

Several predators, including ladybird beetles and common lacewings, feed on scales and mealybugs. Chemical control for scales and mealybugs includes insecticidal oils and varous other insecticides.

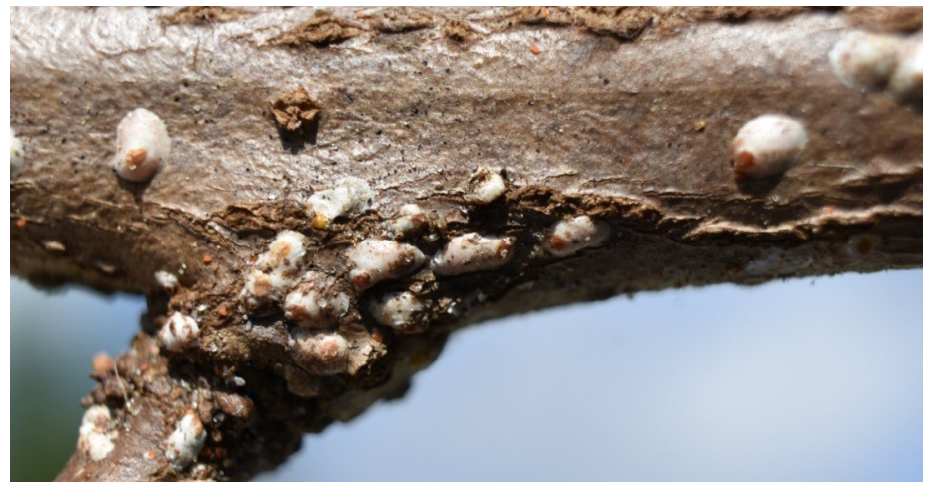

Figure 14. White peach scales on the mature stem of railroad vine. Credits: Stephen H. Brown, UF/IFAS

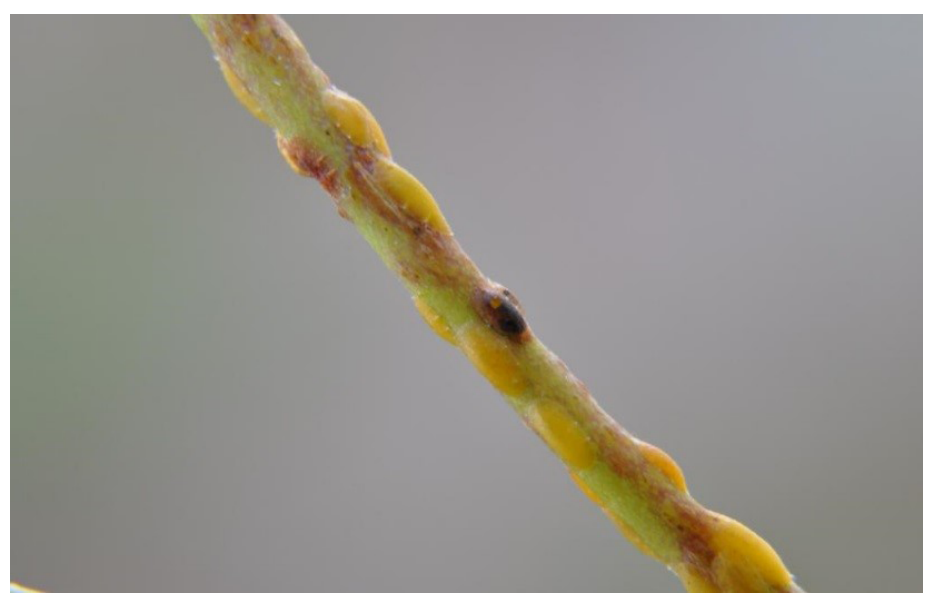

Figure 15. Female Philephedra scales on railroad vine. Credits: Stephen H. Brown, UF/IFAS 


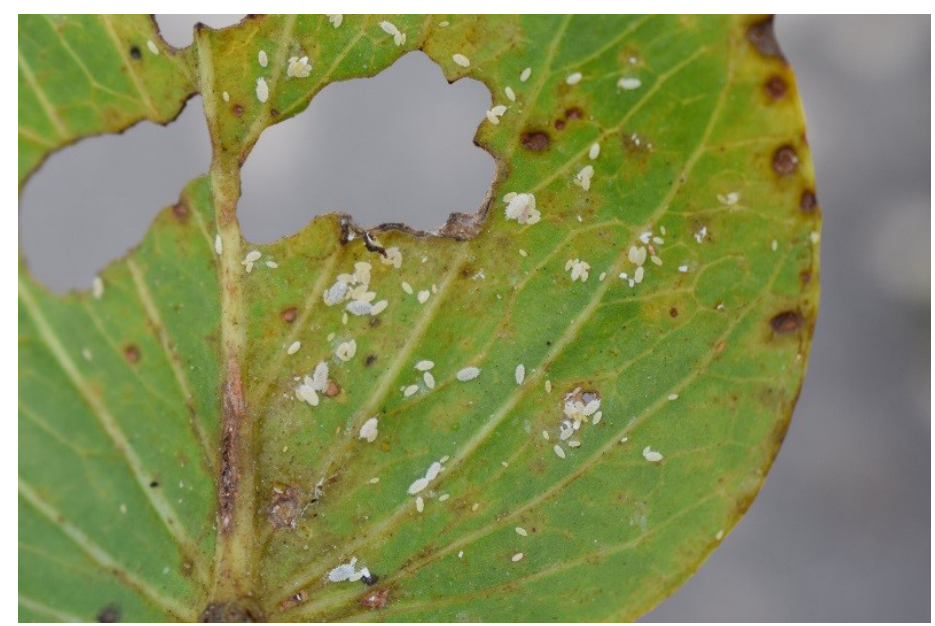

Figure 16. Madeira mealybugs on railroad vine.

Credits: Stephen H. Brown, UF/IFAS

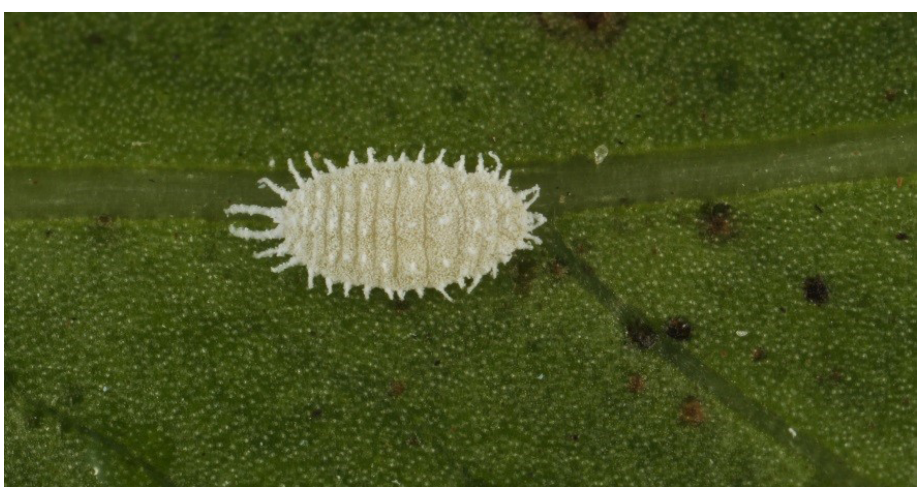

Figure 17. Close-up of adult female Madeira mealybug on railroad vine.

Credits: Lyle Buss, UF/IFAS

\section{Florida Leatherleaf Slug}

Florida leatherleaf (Leidyula floridana) is a tan-colored slug. It often has brown or black spots that coalesece into a single dark stripe on either side of its body and a long, pale, thin stripe down the center of its back. It is native to the Caribbean region and southern Florida. When disturbed or at rest, it is contracted with hidden tentacles. When moving or feeding, it is stretched out with exposed tentacles. It can cause unsightly foliar damage on railroad vine.

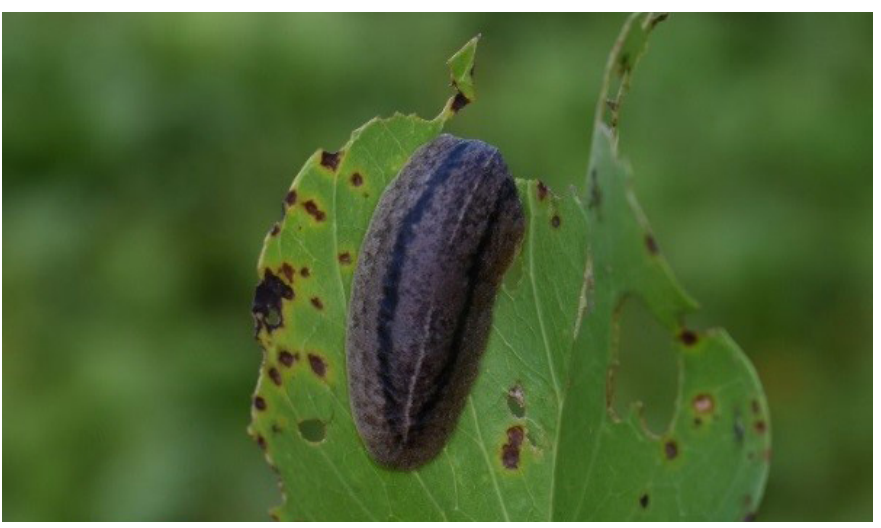

Figure 18. Leatherleaf slug with dorsal dark stripes and a thinner pale stripe in the center.

Credits: Stephen H. Brown, UF/IFAS

\section{Cercospora Leaf Spot}

Leaf spot caused by the parasitic fungi in the genus Cercospora can have devastating effects on dense or mounded ornamental plantings of railroad vine, as well as weakened, sparse patches in coastal habitats. Infection with Cercospora often begins during the warm, moist months of summer and is more likely on sites that are excessively irrigated or poorly drained, or that have reduced sunlight or airflow. Infection usually starts from the bottom of the plant and progresses upward toward the new growth. Leaf spots are usually circular, often surrounded by a red to purple border or halo, and can cover small or large portions of the leaf blade. In older lesions, necrotic areas may develop (the center of the spots becomes brown and the tissue dies, leaving a hole). Under ideal conditions, Cercospora can cause severe defoliation and massive stem dieback.

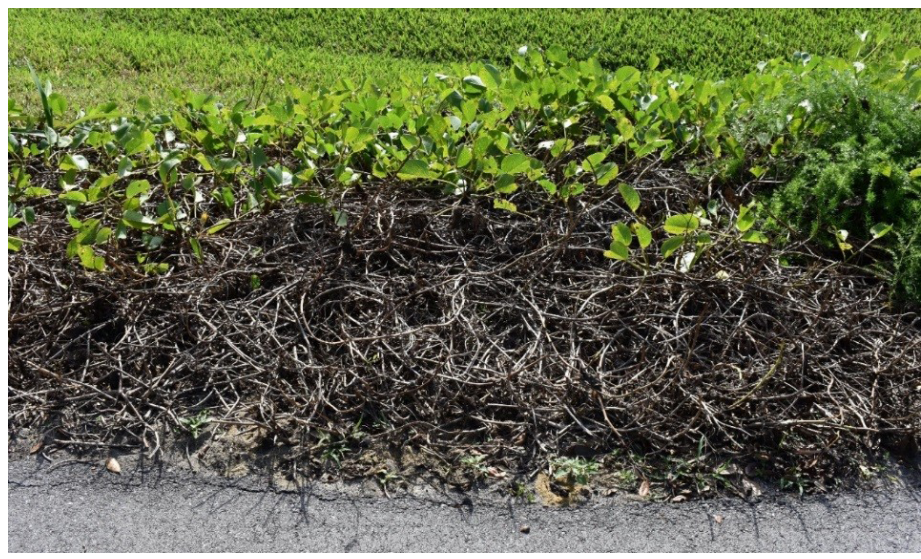

Figure 19. Dieback from Cercospora leaf spot on landscape bed of railroad vine.

Credits: Stephen H. Brown, UF/IFAS

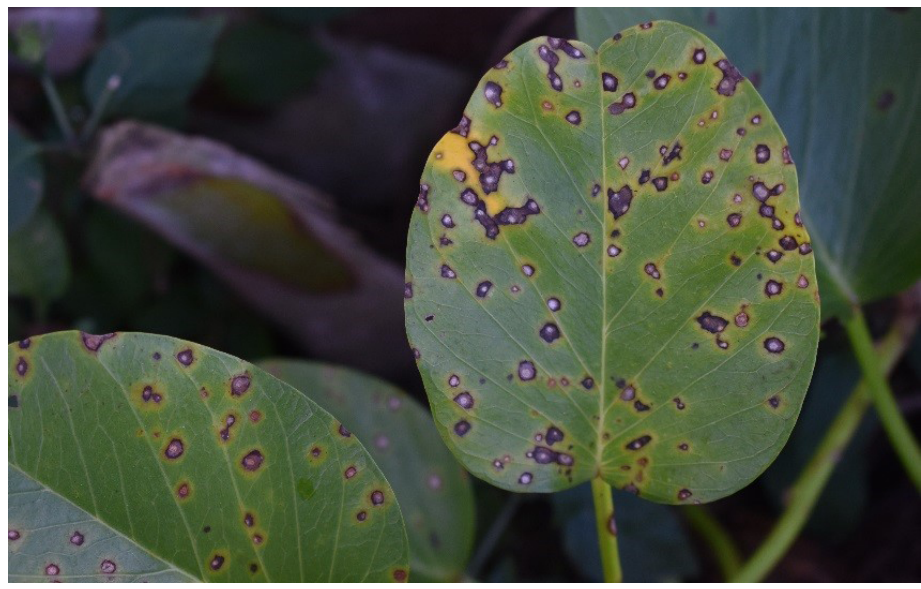

Figure 20. Cercospora leaf spot on railroad vine. Credits: Stephen H. Brown, UF/IFAS

\section{White Rust}

A white rust, caused by the fungus Albugo ipomoeaepanduratae, can cause severe damage, especially to vines used as ornamental groundcovers. It affects leaves, flowers, and stems, resulting in defoliation, reduced flowering, 
and stem dieback. The pathogen is an oomycete similar to Pythium, Phytophthora, and downy mildew pathogens.

Most fungicides labeled for diseases caused by any one of these more common pathogens are likely to be effective for white rust as well. Check the fungicide labels for site clearances, because some have landscape clearance, while other are for nursery or commercial use only. Recommended fungicides include those with the active ingredient azoxystrobin, cyazofamid, mefenoxam, or pyraclostrobin.

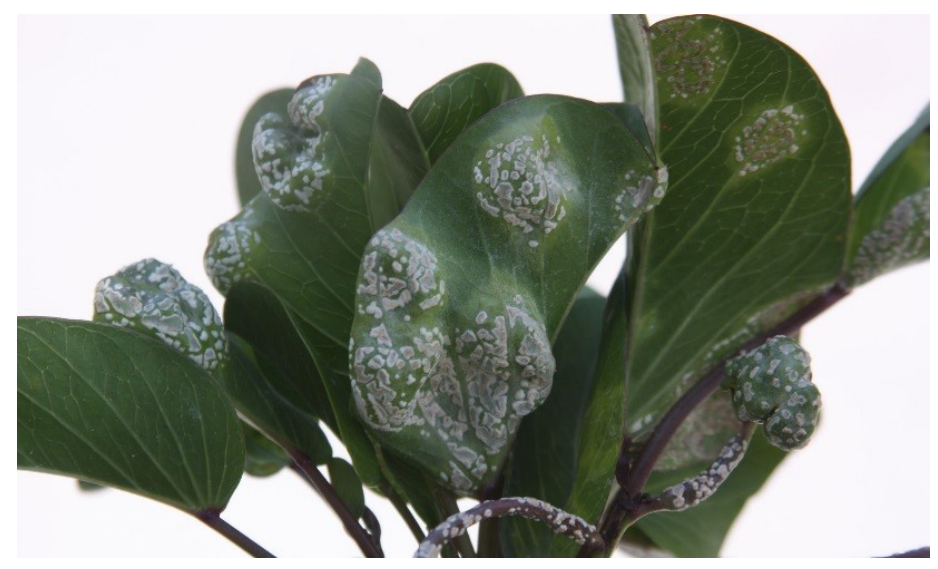

Figure 21. White rust on railroad vine.

Credits: Stephen H. Brown, UF/IFAS

\section{References}

Burrows, G. E., and R. J. Tyrl. 2013. Toxic Plants of North America (2 ${ }^{\text {nd }}$ ed.). Wiley-Blackwell, Ames, Iowa.

Capinera, J. L. 2018. Terrestrial Slugs of Florida (Gastropoda: Stylommatophora). EENY-494. Gainesville: University of Florida Institute of Food and Agricultural Sciences. https:// edis.ifas.ufl.edu/in891

Da Silva, M. W., and E. L. Voght. 2006. "Viability and Germination of Seeds and Initial Development of the Pioneer Dune Plant Ipomoea pes-caprae." Journal of Coastal Research Special Issue No. 39, vol. III: 1255-1258.

Devall, M. S. 1992. "The Biological Flora of Coastal Dunes and Wetlands. 2. Ipomoea pes-caprae (L.) Roth." Journal of Coastal Research 8 (2): 442-456.

Devall, M. S., and L. B. Thien. 1989. "Factors Influencing the Reproductive Success of Ipomoea pes-caprae (Convolvulaceae) around the Gulf of Mexico." American Journal of Botany 76 (12): 1821-1831.

Devall, M. S., and L. B. Thien. 2005. "Inland Occurrence of the Strand Plant Ipomoea pes-caprae (Convolvulaceae) around Lake Nicaragua." The Southwestern Naturalist 50 (3): $380-384$.
Fang, R. C., and G. Staples. 1995. “Ipomoea pes-caprae." In P. Raven and C. Y. Wu (eds.) Flora of China 16:308.

Gann, G. D., C. G. Stocking, K. M. Brennan, K. N. Hines, and collaborators. 2005-2019. "Railroad vine, Bayhops (Ipomoea pes-caprae subsp. brasiliensis).” Natives for Your Neighborhood. The Institute for Regional Conservation, Delray Beach, Florida. https://regionalconservation.org/ beta/nfyn/plantdetail.asp?tx=Ipompes-bras

Gomes Neto, A., S. R. Cunha, and E. L. Voigt. 2004. "Vegetative Propagation of the Dune Building Plant Ipomoea pes-caprae for Use in Dune Rehabilitation Projects." Journal of Coastal Research Special Issue No. 39, vol. III: 1251-1254.

Kane, M. E., K. T. Bird, and T. M. Lee. 1993. "In Vitro Propagation of Ipomoea pes-caprae (Railroad-Vine)." Journal of Coastal Research 9 (2): 356-362.

Miller, D., M. Thetford, C. Verlinde, G. Campbell, and A. Smith. 2018. Dune Restoration and Enhancement for the Florida Panhandle. SGEB-75. Gainesville: University of Florida Institute of Food and Agricultural Sciences.

Miryeganeh, M., K. Takayama, Y. Tateishi, and T. Katjita. 2014. "Long-Distance Dispersal by Sea-Drifted Seeds Has Maintained the Global Distribution of Ipomoea pes-caprae subsp. brasiliensis (Convolvulaceae)." PLOS ONE 9 (4): e91836.

Mondal, A. K., T. Chakraborty, and S. Mondal (Parui). 2013. "Ant Foraging on Extrafloral Nectaries (EFNs) of Ipomoea pes-caprae (Convolvulaceae) in the Dune Vegetation: Ants as Potential Antiherbivore Agents." Indian Journal of Geo-Marine Sciences 42 (1): 67-74.

Nelson, S. 2013. Leaf Spot of Beach Morning-Glory. PD-95. Honolulu: University of Hawaii College of Tropical Agriculture and Human Resources. https://www.ctahr.hawaii.edu/ oc/freepubs/pdf/PD-95.pdf

Staples, G., and E. Er. 2011. "Ipomoea pes-caprae." Convolvulaceae Unlimited. http://convolvulaceae.myspecies.info/ taxonomy/term/7065/descriptions

Staples, G. W., and D. R. Herbst. 2005. A Tropical Garden Flora: Plants Cultivated in the Hawaiian Islands and Other Tropical Places. Honolulu: Bishop Museum Press.

Wunderlin, R. P., B. F. Hansen, and A. R. Franck. 2018. Flora of Florida VI:32. 